\title{
Evaluation of Children Diagnosed with Juvenile Recurrent Parotitis
}

\section{Juvenil Rekürren Parotit Tanısı Alan Çocukların Değerlendirilmesi}

\author{
Nisa Eda Çullas İlarslan' ${ }^{1}$, Fatih Günay', Seda Şahap Kaynak² , Halil Özdemir , Suat Fitöz² , Erdal İnce ${ }^{3}$ \\ ' Department of Pediatrics, Ankara University School of Medicine, Ankara, Turkey \\ ${ }^{2}$ Department of Pediatric Radiology, Ankara University School of Medicine, Ankara, Turkey \\ ${ }^{3}$ Department of Pediatric Infectious Diseases, Ankara University School of Medicine, Ankara, Turkey
}

Cite this article as: Çullas ilarslan NE, Günay F, Şahap Kaynak S, Özdemir H, Fitöz S, Ince E. Evaluation of children diagnosed with juvenile recurrent parotitis. J Pediatr Inf 2019;13(1):e1-e7

\begin{abstract}
Objective: Juvenile recurrent parotitis (JRP) in children is a clinical condition characterized with recurrent episodes of non-obstructive, non-suppurative parotid gland inflammation. Its etiology is not fully understood. We aimed to call attention to JRP, which represents as a diagnostic challenge for many physicians because of its rarity.
\end{abstract}

Material and Methods: We retrospectively reviewed medical charts of children who were diagnosed with JRP at Ankara University Children's Hospital between November 2014-June 2018.

Results: Eleven children ( 6 female, 5 male) with a median age of 5 (2.5$13.5)$ years were identified during the study period. Presenting symptoms were painful parotid swelling $(n=11)$ and fever $(n=7)$. Physical examination revealed firm, smooth and tender parotid swelling (7 unilateral, 4 bilateral). Ultrasonography demonstrated enlarged parotid glands with multiple hypoechoic areas. All children were treated conservatively with analgesics and empirical antibiotics. Evaluation for accompanying diseases revealed ANA positivity in 4 and hypogammaglobulinemia in 3 children. Total recurrence of episodes varied between 1-12 in a follow-up period of 5-44 months.

Conclusion: JRP should be kept in mind in children with repeated episodes of parotitis. The diagnosis is primarily clinical, further confirmed with ultrasonography. Current management is conservative. Evaluation for underlying rheumatologic diseases or immune defects should be considered.

Keywords: Children, parotid gland swelling, recurrent parotitis, ultrasonography
Öz

Giriş: Juvenil rekürren parotit (JRP) parotis bezinin çocukluk çağında görülen tekrarlayıcı nonobstrüktif, nonsüpüratif inflamasyonu ile karakterize bir klinik durumdur. Etyolojisi kesin olarak bilinmemektedir. Bu çaış̧mada, nadir görülmesi nedeniyle birçok klinisyen için tanı konulması güç olan JRP'ye dikkat çekilmesi amaçlanmıştır.

Gereç ve Yöntemler: Ankara Üniversitesi Tıp Fakültesi Çocuk Sağlığı ve Hastalıkları'nda Kasım 2014-Haziran 2018 tarihleri arasında JRP tanısı alan hastaların kayıtları retrospektif olarak incelenmiştir.

Bulgular: Çalışma süresinde medyan yaşları 5 (2.5-13.5) olan toplam 11 çocuk (6 kız, 5 erkek) tespit edildi. Başvuru yakınmaları, parotis bezinde ağrıı şişlik $(n=11)$ ve ateşti $(n=7)$. Fizik incelemede parotis lojunda düzgün sınırlı, sert ve hassas şişlik fark edildi (7 tek taraflı, 4 çift taraflı). Ultrasonografide genişlemiş parotis bezi parankiminde multipl hipoekoik alanlar saptanıldı. Tüm çocuklar analjezikler ve ampirik antibiyotikler ile konservatif olarak tedavi edildi. Eşlik edebilecek patolojiler yönünden yapılan değerlendirmelerde dört hastada ANA pozitifliği ve üç hastada hipogamaglobülinemi saptanıldı. Atakların 5-44 aylık izlem süresince 1-12 kez tekrar ettiği görüldü.

Sonuç: Tekrarlayan parotit ataklarıyla başvuran çocuklarda JRP akılda tutulmalıdır. Hastalığın tanısı klinik olarak konulur ve ultrasonografi ile doğrulanır. Altta yatabilecek romatolojik hastalıklar veya immün defektler yönünden değerlendirmenin yapılması düşünülmelidir.

Anahtar Kelimeler: Çocukluk çağı, parotis bezi şişliği, rekürren parotit, ultrasonografi

\section{Yazışma Adresi / Correspondence Address Nisa Eda Çullas ilarslan \\ Ankara Üniversitesi Tıp Fakültesi, \\ Çocuk Sağlığı ve Hastalıkları Anabilim Dalı, Ankara-Türkiye \\ E-mail: md.eda@hotmail.com}

Received: 28.11 .2018
OCopyright 2019 by Pediatric Infectious Diseases and Immunization Society. Available online at www.cocukenfeksiyon.org 


\section{Introduction}

Juvenile recurrent parotitis (JRP) in children is a rare clinical condition which is characterized with recurrent episodes of non-obstructive and non-suppurative parotid gland inflammation. The etiology of JRP is not fully understood. It presents with mostly unilateral but sometimes bilateral painful parotid swelling, recurring at least twice, usually accompanied by fever and malaise. The orifice of the parotid gland duct is usually dilated and surrounded by white-yellow plaques. Episodes usually manifest between 3-6 years with a male preponderance, last between 1 day and 2 weeks, occur every 3-4 months, and tend to resolve spontaneously during puberty in most patients (1-3).

The diagnosis of JRP is mainly based on history and physical examination findings in children with $\geq 2$ attacks of acute parotitis (4). It may be distinguished from suppurative parotitis by the absence of pus. Preliminary diagnosis is frequently confirmed by the demonstration of "sialectasia" (multiple hypoechoic regions and punctate calcifications) by ultrasonography (US) (4-8).

The treatment of JRP generally consists of relief of acute symptoms and prevention of glandular parenchymal damage. First step measures are maintenance of good oral hygiene, adequate hydration, warm massage to the parotid gland, use of sialogogues and analgesics (7). The administration of antibiotics during attacks is controversial. Although many authors suggest their use, some do not agree (9-11). More recently, increasing evidence indicate success of sialendoscopy in the diagnosis and treatment of JRP $(12,13)$.

This study aimed to draw attention to JRP, a rare clinical condition, which represents as a diagnostic challenge for many physicians. For this purpose, we retrospectively reviewed the medical charts of children diagnosed with JRP. Under the light of our findings and review of the literature, we aimed to emphasize the diagnosis, management and outcome of this condition.

\section{Materials and Methods}

\section{Patients and Study Design}

This retrospective cohort study was conducted in Ankara University Children's Hospital. We have reviewed the medical charts of eleven children who were diagnosed with JRP between November 2014-June 2018. Diagnosis of juvenile recurrent parotitis was made clinically in children with $\geq 2$ attacks of acute non-suppurative parotitis, and further confirmed with US. Exclusion criteria were outlined as incomplete data and detection of a mass lesion (eg. stone, tumor) located in the parotid gland ducts.
A comprehensive history including the age of initiation, duration, laterality and frequency of the episodes were recorded for each patient. Familial occurrence, signs suggestive of autoimmune diseases (eg. skin rash, dry mouth, dry eyes or joint swelling), as well as immune deficiencies were evaluated. Physical examination findings with particular attention on parotitis were reviewed.

The results of acute phase reactants [(erythrocyte sedimentation rate, serum C-reactive protein (CRP)] and serum amylase levels, immune function tests (absolute lymphocyte and neutrophil counts, immunoglobulin G, A, M levels), serum rheumatoid factor, autoantibody profile [antinuclear antibodies (ANA), anti-double stranded DNA (anti-dsDNA) antibodies, anti-RNP antibodies, anticardiolipin, anti-smooth muscle antibody (anti-SMA), antiphospholipid antibodies and anti-Ro (SS-A), anti-La (SS-B) antibodies], serum complement levels (C3, C4), and infectious markers (anti-mumps Ig M, anti HAV IgM, HbsAg, anti $\mathrm{HCV}$, anti HIV, anti CMV IgM, anti EBV IgM, anti-toxoplasma IgM) were evaluated. Ultrasound findings and results of other imaging studies if available (eg. MRI, CT), treatment modalities and clinical outcomes were noted for each patient. Phone contacts with families were carried out to gather information about long term outcome in case of inadequate data.

Ethical approval: The study protocol was approved by Ankara University Clinical Research Ethical Commitee (Study approval number: 11-732-18, June 2018).

\section{Statistical Analysis}

Statistical analysis of this study was performed using the SPSS statistical package (v.21.0). Comparison analysis were not made as it was designed as a descriptive study. Counts and percentages for categorical variables; median values and ranges for continuous variables were reported.

\section{Results}

A total of 11 children ( 6 female, 5 male) with a median age of $5(2.5-13.5)$ years were identified during the study period. The median age of presentation of episodes was 3 (2-7) years. Three patients were diagnosed following their second attack while number of previous episodes before diagnosis was at most 25 . The time period between the initiation of symptoms and time of diagnosis varied between 2 months and 6.5 years.

Ten of these patients received mumps vaccine in accordance with our universal vaccination schedule. All patients signified a prior diagnosis of mumps concerning their first episode of parotitis. Episodes were treated conservatively $(n=9)$ or with antibiotics $(n=2)$ prior to diagnosis of JRP. None of the patients signified a family history of recurrent parotitis. One patient's father was learned to have a diagnosis of ankylosing spondylitis. Signs related with autoimmune diseases (eg. skin rash, arthritis, 
dry eyes or dry mouth) were not mentioned by any family. Two patients denoted frequent use of antibiotics for upper respiratory tract infections.

All children presented with painful parotid swelling. Seven children had fever during episodes. Physical examination revealed firm, smooth and tender parotid swelling. Parotid swelling was unilateral in 7 patients and bilateral in 4 patients. Local erythema of the overlying skin was observed in five patients. There was no pus when pressure was applied to the Stenson's duct opening. The episodes lasted between 3-10 days. The de- mographic and clinical characteristics of children diagnosed with JRP are shown in Table 1.

Laboratory investigations are listed in Table 2. Leukocytosis and increased acute phase reactant levels were observed in some patients. All patients had high serum amylase level $(>100$ $\mathrm{U} / \mathrm{L}$ ). Acute infectious markers including anti-mumps Ig $\mathrm{M}$ were negative in all children.

All patients were evaluated for accompanying illnesses, such as autoimmune diseases and immunodeficiencies. Auto-

Table 1. Demographic and clinical characteristics of children diagnosed with juvenile recurrent paratitis

\begin{tabular}{|c|c|c|c|c|c|c|}
\hline & Gender & Age at onset & $\begin{array}{c}\text { Number of previous } \\
\text { episodes }\end{array}$ & $\begin{array}{c}\text { Age of } \\
\text { diagnosis }\end{array}$ & Laterality of episodes & $\begin{array}{c}\text { Duration of episodes } \\
\text { (day) }\end{array}$ \\
\hline Case 1 & $\mathrm{~F}$ & 7 & 2 & 8 & Unilateral (Right) & $4-7$ \\
\hline Case 2 & $\mathrm{~F}$ & 7 & 1 & 7 & Unilateral (Right) & $3-4$ \\
\hline Case 3 & $\mathrm{~F}$ & 2 & 2 & 3.5 & Unilateral/bilateral & 7 \\
\hline Case 4 & M & 2.5 & 1 & 2.5 & Unilateral/bilateral & 5 \\
\hline Case 5 & M & 2.5 & $\sim 20$ & 4.5 & Unilateral/bilateral & 5 \\
\hline Case 6 & $\mathrm{~F}$ & 3 & 6 & 9.5 & Unilateral (Left) & 3 \\
\hline Case 7 & $\mathrm{~F}$ & 7 & 7 & 13.5 & Unilateral (Left) & $4-6$ \\
\hline Case 8 & M & 3 & 5 & 3.25 & Bilateral, prominent on left & 8-10 \\
\hline Case 9 & $M$ & 2 & 1 & 2.5 & Unilateral (Right) & 6 \\
\hline Case 10 & $\mathrm{~F}$ & 4.5 & $\sim 25$ & 6.5 & Unilateral (Right) & $5-8$ \\
\hline Case 11 & M & 4.5 & 3 & 5 & Unilateral (Right) & $2-3$ \\
\hline
\end{tabular}

Table 2. Laboratory investigations and accompanying diseases of children

\begin{tabular}{|c|c|c|c|c|c|c|c|}
\hline & WBC/ANC & $\begin{array}{c}\text { ESR } \\
(\mathrm{mm} / \mathrm{hr})\end{array}$ & $\begin{array}{c}\text { CRP } \\
(\mathrm{mg} / \mathrm{dL})\end{array}$ & $\begin{array}{c}\text { Amylase } \\
\text { (U/L) }\end{array}$ & $\begin{array}{c}\text { Autoimmune } \\
\text { markers }\end{array}$ & $\begin{array}{c}\text { Immune function } \\
\text { tests }\end{array}$ & $\begin{array}{c}\text { Infectious } \\
\text { markers }\end{array}$ \\
\hline Case 1 & $16700 / 13500$ & 16 & 2.7 & 335 & $\begin{array}{c}\text { ANA +1 } \\
\text { (weak nuclear staining) }\end{array}$ & Normal & Negative \\
\hline Case 2 & $15600 / 8500$ & 48 & 14.4 & 246 & Negative & Normal & Negative \\
\hline Case 3 & $14400 / 9400$ & 54 & 17 & 488 & Negative & Normal & Normal \\
\hline Case 4 & $9300 / 4600$ & 11 & 15.5 & 213 & Negative & Normal & Negative \\
\hline Case 5 & $9950 / 5000$ & 5 & 1.7 & 223 & Negative & Low $\lg A$ & Negative \\
\hline Case 6 & $9000 / 3860$ & 4 & 2.1 & 110 & $\begin{array}{c}\text { ANA +1 } \\
\text { (weak dense staining) }\end{array}$ & Normal & Negative \\
\hline Case 7 & $7570 / 3460$ & 4 & 8 & 621 & $\begin{array}{c}\text { ANA +2 } \\
\text { (cytoplasmic staining) }\end{array}$ & Normal & Negative \\
\hline Case 8 & $10300 / 5600$ & 4 & 6.9 & 153 & $\begin{array}{c}\text { ANA +1 } \\
\text { (weak dense staining) }\end{array}$ & Low $\lg M$ & Negative \\
\hline Case 9 & $17000 / 9500$ & - & 34.4 & 178 & Negative & Low $\lg A$ & Negative \\
\hline Case 10 & $6070 / 2630$ & 28 & 22 & 116 & $\begin{array}{c}\text { ANA +1 } \\
\text { (weak dense staining), Anti-RNP + }\end{array}$ & Normal & Negative \\
\hline Case 11 & 10730/7230 & 30 & 11 & 149 & Negative & Normal & Negative \\
\hline
\end{tabular}


Table 3. Serum immunoglobulin levels of children with juvenile recurrent parotitis

\begin{tabular}{|l|c|c|c|}
\hline g/L (normal reference values for age) & Immunoglobulin A & Immunoglobulin M & Immunoglobulin G \\
\hline Case 1 & $2.94(0.7-3.03)$ & $0.95(0.69-3.87)$ & $12.50(7.64-21.34)$ \\
\hline Case 2 & $1.91(0.7-3.03)$ & $1.20(0.69-3.87)$ & $7.91(7.64-21.34)$ \\
\hline Case 3 & $0.47(0.26-2.96)$ & $1.09(0.71-2.35)$ & $7.48(6.04-19.41)$ \\
\hline Case 4 & $0.83(0.26-2.96)$ & $1.01(0.71-2.35)$ & $6.69(6.04-19.41)$ \\
\hline Case 5 & $0.06(0.26-2.96)$ & $1.43(0.71-2.35)$ & $10.7(6.04-19.41)$ \\
\hline Case 6 & $0.69(0.44-2.44)$ & $2.30(0.78-2.61)$ & $9.10(6.4-20.10)$ \\
\hline Case 7 & $1.21(0.7-3.03)$ & $1.74(0.69-3.87)$ & $12.5(7.64-21.34)$ \\
\hline Case 8 & $1.309(0.44-2.44)$ & $0.34(0.78-2.61)$ & $8.10(6.4-20.10)$ \\
\hline Case 9 & $0.15(0.26-2.96)$ & $0.82(0.71-2.35)$ & $7.94(6.04-19.41)$ \\
\hline Case 10 & $2.08(0.57-2.82)$ & $1.59(0.78-2.61)$ & $14.10(7.45-21.34)$ \\
\hline Case 11 & $1.86(0.57-2.82)$ & $1.16(0.78-2.61)$ & $9.68(7.45-21.34)$ \\
\hline \multicolumn{1}{|l}{} & & \\
\hline
\end{tabular}
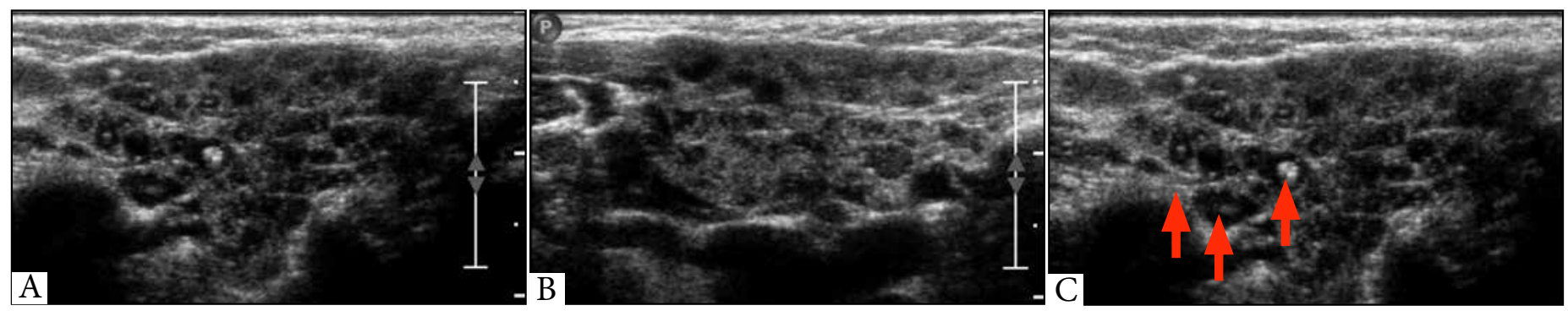

Figure 1. (A,B): Ultrasound images of the left and right parotid gland showing heterogeneous texture with multiple hypoechoic foci suggesting sialectasis. (C) Multiple hyperechoic central foci of salivary gland secretions are also seen.

immune marker evaluation showed positive ANA titers in four patients. Three of these patients were consulted to pediatric rheumatology. Even though a specific diagnosis was not made because of the absence of additional positive findings suggestive of a rheumatologic disease, follow-up was recommended. Other autoimmune markers including antibodies for Sjogren's syndrome (SS-A, SS-B) were negative in all patients. Immune function tests delineated low $\lg A$ in two patients and low $\lg M$ in one patient (Table 3). As exact discrimination between transient hypogammaglobulinemia of infancy and selective hypogamaglobulinemia (Ig A or $\lg \mathrm{M}$ ) could not be accomplished, definitive diagnosis were assumed to be made in the follow-up. Pediatric immunology consultation resulted with no additional immunologic defect.

Ultrasonographic evaluation revealed unilateral or bilateral enlarged parotid glands with multiple hypoechoic areas within the parenchyma (Figure 1). Ductal stones, abscesses or mass lesions were not detected in any patient. Incidentally, patient 2 had cranial MRI 3 months later because of epilepsy, which signified heterogeneous parenchyma with sialoectatic foci in both parotid glands.
All children were treated conservatively with analgesics and empirical antibiotics (amoxicillin-clavulanate $[50 \mathrm{mg} / \mathrm{kg} /$ day, 7 days]). Follow-up period of eleven patients varied from 5 to 44 months. Number of repeated attacks following diagnosis varied from 1 to 12 (Table 4).

\section{Discussion}

Recurrent parotitis in children is defined as intermittent inflammation of one or both parotid glands. Although the exact incidence is not clear, it is known as a rare clinical condition, since most reports consist of small case series $(4,9,14)$. Even so, JRP was referred as the second most frequent disease of the parotid gland in children after mumps before the implementation of mumps vaccine in many countries $(15,16)$. Herein, we have presented our series to raise awareness to this clinical entity.

Although the pathophysiology of JRP is not fully elucidated, it is believed to be multifactorial. One possible explanation is reduced flow or modified content of saliva which induces stasis, recurrent retrograde inflammation and thus damage to the ductules, with further development of sialectasis over time $(5,9)$. Another theory suggests that baseline structural 
Table 4. Accompanying diseases and follow-up findings of children with JRP

\begin{tabular}{|c|c|c|c|c|}
\hline & Further consultation & Accompanying diseases & $\begin{array}{l}\text { Period of follow-up } \\
\text { (months) }\end{array}$ & $\begin{array}{l}\text { Number of recurrences } \\
\text { following diagnosis }\end{array}$ \\
\hline Case 1 & - & - & 44 & 1 \\
\hline Case 2 & - & - & 38 & 1 \\
\hline Case 3 & - & - & 47 & 2 \\
\hline Case 4 & - & - & 42 & 7 \\
\hline Case 5 & Immunology & Ig A deficiency & 33 & 12 \\
\hline Case 6 & Rheumatology & No specific diagnosis, follow-up recommended & 5 & 1 \\
\hline Case 7 & Rheumatology & No specific diagnosis, follow-up recommended & 18 & 3 \\
\hline Case 8 & Immunology & $\lg$ M deficiency & 5 & 1 \\
\hline Case 9 & Immunology & Ig A deficiency & 5 & 1 \\
\hline Case 10 & Rheumatology & No specific diagnosis, follow-up recommended & 6 & 3 \\
\hline Case 11 & - & - & 5 & 1 \\
\hline
\end{tabular}

abnormalities of the gland ductules represent as the main trigger for recurrent inflammation (9). Furthermore, genetic factors, dental malocclusion, viral infections, autoimmune diseases (eg. Sjogren's), allergy, sarcoidosis and immune defects such as selective Ig A deficiency have all been reported as accompanying diseases $(4,6,14,17-19)$.

Even though our data can not be generalized for JRP because of the small size of our study group, we observed that the age of onset of episodes (2.5-7 years) showed a similar pattern with the existing literature (3-6 years) (1). Leerdam et al. have carried out the most comprehensive clinical trial concerning recurrent parotitis of childhood (9). They have encountered the median duration of episodes as 3 (2-7) days in their retrospective trial including 53 children diagnosed with JRP. They also observed diagnosis without a delay in only $30 \%$ of their series. Similarly, our patients presented with episodes lasting between 3-10 days, and only 3 out of 10 children were diagnosed in less than 6 months following the initiation of symptoms. The frequency and severity of episodes tend to subside up to puberty. Proposed mechanisms for this resolution are total atrophy or regeneration of the parotid glands over time (20).

The diagnosis of JRP is primarily clinical. Leerdam et al. reported the most frequent clinical findings as parotid swelling, pain and fever in their series (9). We observed similar findings in our study. Moreover, sialogram identifies multiple punctate collections indicating sialectasis. Currently, this invasive procedure has been replaced by US, which is non-invasive, easily applicable, and proven to be as sensitive as sialography (9). Ultrasonography also rules out mass lesions, stones and abscess. Papadopoulou-Alataki et al. reported parotid swell- ing and intraparotid lymph nodes in all, and microabscesses in $30 \%$ of their study population (7). Miziara et al. reported heterogeneous aspect, hypoechoic areas and intraparotid lymph nodes in their cases diagnosed with JRP (5). Compatible with previous research, our choice of investigation was US, which documented enlarged parotid glands with multiple hypoechoic areas. Additionally, small cystic lesions with microcalcified walls as a result of chronic inflammation may be visualized with computed tomography (CT) and magnetic resonance imaging (MRI) of the parotid gland $(9,21)$. Currently, these investigations are not routinely implemented for the diagnosis of JRP for the disadvantage of irradiation risk in CT and lack of ready availability of MRI. Magnetic resonance imaging, which was undertaken for another indication, demonstrated heterogeneous parenchyma with sialoectatic foci in both parotid glands in one of our patients.

All of our patients were diagnosed with mumps following their first episodes. This finding is striking because of the existence of mumps vaccine in our routine vaccination schedule, keeping in mind the high protection feature of this vaccine. Acute infectious markers were negative for all cases. Guisa et al. and Bazsis et al. recommend evaluation for rheumatologic diseases in children with JRP $(6,19)$. Cimas et al. emphasized that Sjogren syndrome in children rarely show sicca symptoms at presentation while parotitis is frequently present (22). Our patients had negative history for rheumatologic diseases. Rheumatologic markers including Sjogren antibodies were negative in our patients. Three patients with positive ANA titer are still followed up by rheumatology. Additionally, JRP has occasionally been associated with immunodeficiencies, especially selective Ig A deficiency $(18,23,24)$. Based on the published literature, we have evaluated our series for immune 
defects and encountered low immunoglobulin levels in three children.

There has been no consensus on appropriate treatment of JRP in children. Given the fact that the condition usually carries good prognosis, many authors suggest conservative measures, mainly consisting of hydration and analgesics (9). The administration of antibiotics remains as a matter of debate as evidence of bacterial involvement in JRP is insufficient. Furthermore, studies comparing the outcome of patients with and without antibiotic treatment don't exist. Chitre et al. and Nahlieli et al. recommended use of antibiotics for the prevention of additional parenchymal damage $(2,25)$. On the other hand, Isaacs et al advocated against the use of antibiotics (10). They proposed no benefit of antibiotics on the outcome of attacks. Leerdam et al. suggested avoidance of antibiotics unless complications, such as abscess or cellulitis occur (9). More recently, increasing evidence indicate success of sialendoscopy in the diagnosis and treatment of JRP $(12,13)$. A meta-analysis by Canzi et al. showed high success and a very low recurrence rate after sialendoscopy and lavage with saline solutions or corticosteroids (26). We did not refer our patients to otorhinolaryngology for sialendoscopy. Although our patients generally experienced less severe episodes with shorter duration in the follow-up, two patients had frequently repeated (7 and 12) episodes.

\section{Conclusion}

Juvenile recurrent parotitis should be kept in mind in children with repeated episodes of parotitis. The diagnosis is primarily clinical. A non-invasive imaging study, such as ultrasonography, should be considered to confirm the diagnosis and rule out mass lesions. Families should be informed that this condition is usually self-limiting, and episodes resolve by puberty. Current management is conservative. Evaluation for underlying rheumatologic diseases or immune defects is recommended.

Ethics Committe Approval: The study protocol was approved by Ankara University Clinical Research Ethical Commitee (Study approval number: 11-732-18, June 2018).

Informed Consent: As it was a retrospectively designed study, only verbal consent was available from patients contacted with telephone.

Peer-review: Externally peer-reviewed.

Author Contributions: Concept - NEÇi; Design - NEÇI, FG; Supervision - El, FS, HÖ; Materials - NEÇI, SŞK; Data Collection and/or Processing - NEÇI, FG; Analysis and/or Interpretation - NEÇI, FG, SŞK, EI, SF, HÖ; Literature Review - NEÇI, SŞK; Writing - NEÇI, El, SF; Critical Review - El, FS, HÖ.

Conflict of Interest: No conflict of interest was declared by the authors.

Financial Disclosure: The authors declared that this study has received no financial support.

\section{References}

1. Bhattarai M, Wakode PT. Recurrent parotitis in children. J Indian Assoc Pediatr Surg 2006;11:246-8.

2. Nahlieli $O$, Shacham $R$, Shlesinger $M$, Eliav E. Juvenile recurrent parotitis: a new method of diagnosis and treatment. Pediatrics 2004;114:9-12.

3. Capaccio P, Sigismund PE, Luca N, Marchisio P, Pignataro L. Modern management of juvenile recurrent parotitis. J Laryngol Otol 2012;126:125460 .

4. Li NW, Chan WM, Kwan YW, Leung CW. Recurrent parotitis in children. HKJ Paediatr (New Series) 2011;16:36-40.

5. Miziara ID, Campelo VE. Infantile recurrent parotitis: follow up study of five cases and literature review. Braz J Otorhinolaryngol 2005;71:570-5.

6. Guissa VR, Martinelli EL, Brandão LMKR, Garcia LD, Provenza JR, Mendonça JA. Sonographic evaluation of salivary glands in juvenile Sjögren's syndrome. Acta Reumatol Port 2018;43:61-5.

7. Papadopoulou-Alataki E, Chatziavramidis A, Vampertzi O, Alataki S, Konstantinidis I. Evaluation and management of juvenile recurrent parotitis in children from northern Greece. Hippokratia 2015; 19:356-9.

8. Sodhi KS, Bartlett M, Prabhu NK. Role of high resolution ultrasound in parotid lesions in children. Int J Pediatr Otorhinolaryngol 2011;75:13538.

9. Leerdam CM, Martin HC, Isaacs D. Recurrent parotitis of childhood. $J$ Paediatr Child Health 2005;41:631-4.

10. Isaacs D. Recurrent parotitis. J Paediatr Child Health 2002;38:92-4.

11. Becerir C, Ergin H, Karabulut N, Orhan Kara C. Altı yaşında bir çocukta tekrarlayan parotitis $A$ six-year-old child with recurrent parotitis. Pam Med J 2012;5:136-8.

12. Roby BB, Mattingly J, Jensen EL, Gao D, Chan KH. Treatment of juvenile recurrent parotitis of childhood: an analysis of effectiveness. JAMA Otolaryngol Head Neck Surg 2015;141:126-9.

13. Berta E, Angel G, Lagarde F, Fonlupt B, Noyelles L, Bettega G. Role of sialendoscopy in juvenile recurrent parotitis (JRP). Eur Ann Otorhinolaryngol Head Neck Dis 2017;134:405-7.

14. Bernkopf E, Colleselli P, Broia V, de Benedictis FM. Is recurrent parotitis in childhood still an enigma? Acta Paediatr 2008;97:478-82.

15. Canzi P, Occhini A, Pagella F, Marchal F, Benazzo M. Sialendoscopy in juvenile recurrent parotitis: a review of the literature. Acta Otorhinolaryngol Ital 2013;33:367-73.

16. Quenin S, Plouin-Gaudon I, Marchal F, Froehlich P, Disant F, Faure F. Juvenile recurrent parotitis: sialendoscopic approach. Arch Otolaryngol Head Neck Surg 2008;134:715-9.

17. Alp H, Orbak Z, Erdogan T, Karabag K, Gursan N. Recurrent parotitis as a first manifestation in a child with primary Sjogren's syndrome. West Indian Med J 2011;60:685-7.

18. Akar HH, Patıroglu T, Duman L. A selective IgA deficiency in a boy who presented recurrent parotitis. Eur J Microbiol Immunol (Bp) 2014;4:1446.

19. Baszis K, Toib D, Cooper M, French A, White A. Recurrent parotitis as a presentation of primary pediatric Sjögren syndrome. Pediatrics 2012;129:e179-82.

20. Galili D, Marmary Y. Juvenile recurrent parotitis: clinicoradiologic follow-up study and the beneficial effect of sialography. Oral Surg Oral Med Oral Pathol 1986;61:550-6.

21. Sitheeque $M$, Sivachandran $Y$, Varathan $V$, Ariyawardana $A$, Ranasinghe A. Juvenile recurrent parotitis: clinical, sialographic and ultrasonographic features. Int J Paediatr Dent 2007;17:98-104. 
22. Cimaz R, Casadei A, Rose C, Bartunkova J, Sediva A, Falcini F, et al. Primary Sjögren syndrome in the paediatric age: a multicentre survey. Eur J Pediatr 2003;162:661-5.

23. Fazekas T, Wiesbauer P, Schroth B, Pötschger U, Gadner H, Heitger A. Selective IgA deficiency in children with recurrent parotitis of childhood. Pediatr Infect Dis J 2005;24:461-2.

24. Shkalim V, Monselise Y, Mosseri R, Finkelstein Y, Garty BZ. Recurrent parotitis in selective IgA deficiency. Pediatr Allergy Immunol 2004;15:281-3.
25. Chitre VV, Premchandra DJ. Recurrent parotitis. Arch Dis Child 1997;77:359-63.

26. Canzi P, Occhini A, Pagella F, Marchal F, Benazzo M. Sialendoscopy in juvenile recurrent parotitis: a review of the literature. Acta Otorhinolaryngol Ital 2013;33:367-73. 